Article

\title{
Farmers' Perception of Precision Farming Technology among Hungarian Farmers
}

\author{
Enikő Lencsés ${ }^{1}$, István Takács ${ }^{2}$ and Katalin Takács-György ${ }^{2, *}$
}

1 Faculty of Economics and Social Sciences, Szent István University, H-2100 Gödöllö, Páter Károly u. 1, Hungary; E-Mail: lencses.eniko@gtk.szie.hu

2 Károly Róbert College, H-3200 Gyöngyös, Mátrai u. 36, Hungary; E-Mail: itakacs@karolyrobert.hu

* Author to whom correspondence should be addressed; E-Mail: tgyk@karolyrobert.hu; Tel.: +36-38-518-297.

External Editor: Marc A. Rosen

Received: 3 June 2014; in revised form: 16 November 2014 / Accepted: 18 November 2014 /

Published: 25 November 2014

\begin{abstract}
Many technologies have appeared in agriculture to reduce the harmful effects of chemical use. One of these technologies is precision farming technology. Precision farming technology should not be considered as only the latest plant production technology or only a new agro-management tool. It is achieved only when the results of electronics and IT equipment are realized in the variable rate treatments zone-by-zone. The advantages and disadvantages of this technology highly depend on the heterogeneity of soil, the knowledge and attitude of the manager and the staff. This is the reason why opinions about the technology effects are so wide. This paper shows the results of the investigation based on interviews about the adoption and knowledge of precision farming technology among Hungarian crop producers. This technology is mostly used by farms over 300 hectares with young farmers. The most characteristic elements were precision fertilization and tractor guidance. The survey examined three groups of farmers with respect to whether they apply precision farming elements or not. We refer to them as "users", "planners" and "non-users". According to the survey, the opinions of the "user" and the "non-user" groups of farmers are not significantly different regarding the impacts of precision farming technology (the main advantages were the change in yield quantity, chemical usage and income). Furthermore, the opinions of the farmers regarding the changes in variable costs resulting from the adoption of precision farming technology were also examined (measured in percent). Box-plot
\end{abstract}


analysis was used for this examination. According to the opinion of the "user" group of farmers, the highest cost savings occurred in fertilizer and herbicide costs.

Keywords: cost savings; site-specific plant production; environmental impact

\section{Introduction}

In agricultural innovation, the ecological and economical sustainability of production play a very important role. The heart of sustainable agriculture is to hold the balance between economic, social and environmental expectations [1,2]. The radical changes of natural resources go along with the change of the structure of agricultural production and make it necessary to introduce alternative technologies, for example ecological farming, mid-tech farming and precision farming. These processes should be supported by new types of allowances, including those elements that focus on the increase of efficiency [3-7]. All over the world, the common challenges of agriculture are to satisfy growing food demand on smaller and smaller agricultural area, to avoid environmental damage and to produce high quality products with profit.

The future of agricultural production is to keep the (artificial or natural) input usage within a reasonable level and to spread out only the amount that is necessary for the produced plant considering the heterogeneous conditions of the field and no more. The central idea of precision farming technology is to rationalize the inputs site-specifically from zone to zone on the field and not on the average of the field. These zones are the basis of input optimization and treatment decisions. The advantages of site-specific treatments can be achieved by using a high technical level in a responsible way. The farmers are faced with the fact that when there is a rapid rate change, the applicator needs time until he is able to distribute the target amount of fertilizer [8]. The size of the treatment units (management zones), the multiples of the required working width, have to be taken into account. The question concerning the size of the management zone is difficult to answer. It depends on the heterogeneity of the soil, weed density, the size of the farm and, in many cases, on financial conditions. For example, based on field experience, Barkaszi et al. $[9,10]$ concluded that the sampling method is reliable only for surveying the frequent weed species in the parcel, while more rarely found weeds (e.g., spots of perennials) are to be sampled only by means of going over the parcel and recording them by Global Positioning System (GPS). The sample sizes can be the basis of herbicide treatments, regarding the costs of sampling [11]. The extra costs of weed sampling need to be taken into account, besides the savings resulting from the reduction of herbicide use.

Professionally established weed management assumes exact knowledge of weed infestation in the zone [12]. Weed sampling techniques provide the opportunity to obtain the information on the weed species and on their dynamics of development [13]. Some authors underline the importance of taking the type of crops into consideration and the fact that site-specific fertilizer use is introduced into the technology [14].

The importance of site-specific chemical treatment in sustainable agriculture lies in the fact that precision farming technology is able to apply herbicides at a lower dose, thus reducing environmental harm and minimizing the risk to the environment. Thanks to the zone-to-zone input rationalization and 
treatment, precision technology may ensure more efficient production with a lower environmental impact [15-20]. Accuracy is necessary during the correct application of precision technology, but often, this becomes a factor that obstructs its use on farms [21].

The use of precision farming technology can result in the reduction of the amount of agrochemicals distributed in the environment, and it could also be one of the basic pillars of efficient agriculture, until large-scale production structure, investments, organizational structures and operational mechanisms remain. Earlier studies estimated a 20-60 percent pesticide savings owing to precision plant protection and a $0-30$ percent savings in fertilizer use depending on yield homogeneity [18-20,22]. Furthermore, for the producer, this method of farming can be a tool for reducing the risk of production [23].

Precision farming technology should not be considered as a modern plant production technology. It is also a modern management tool for monitoring work, time, inputs and also helps in making better decisions about production. Precision farming technology means site-specific and variable rate treatments. Furthermore, application maps are necessary for it, which are based on soil sampling with Differential Global Positioning System (DGPS), yield mapping and the tractor guidance system, which decrease overlapping and extra input during the treatment. Numerous international and Hungarian research papers have been published about the technology elements of precision farming (yield mapping, precision sowing, precision nutrient supply and precision weed management) from its introduction in the early 1990s. Precision farming technology is older than 20 years, but it is still evolving and spreading. The focus points of the latest developments are the precision of the treatment and the wider scale of adoption.

Many farmers know about or at least have already heard about the advantages and disadvantages of precision farming technology. However, numerous farmers think that they are not able to introduce and operate precision farming technology, because of the high investment cost. Another barrier to the spread of precision farming technology among the farmers is that the theoretical advantages of the technology may highly depend on the heterogeneity of the field, the knowledge and skill of the operational staff and the commitment of the management in practice. Ensuring the financial background of the adoption of precision farming technology is not enough for its successful operation; the active participation and positive attitude of the farmer and the full staff are also necessary.

Precision farming technology can be considered as a "technology push"; in other words, demand-creating innovation. According to some economic theories, demand-creating innovations can be expected to diffuse if the use of limited resources with new technology results in economic efficiency. The diffusion of precision crop production and its wide-spread application in practice is an economic decision on the farmers' side when they have to invest their capital. Thus, it is not sufficient to examine the changes in the variable costs incurred by production, but it is also important to consider the changes in product prices, as well as the interest rate of credits, so that farmers can make a reasonable decision [24-26].

Agricultural innovation is generally not generated by farmers in Hungary. The main reasons are the polarized and highly fragmented farm structure and the lack of capital. The lack of entrepreneurial affinity must also be taken into account. Cooperation could help, but the attitude of farmers toward cooperation can be characterized by a lack of willingness, and most Hungarian farmers want to own their machinery; and if they do not have the necessary capital for investing in buying the new technology, they give it up [27]. To implement all of the necessary machines and other facilities, the farmers can buy the technical services from providers; they can establish producer cooperatives, for example in the framework of machinery rings [28-33]. The cooperation of several different actors in the food chain is 
necessary in the case of precision technology, although the process is different from the market-focused technology development system proposed by Fenyvesi and Erdei-Késmárki-Gally [34].

Based on Rogers' typology of the diffusion of innovation [35], precision crop production as an agricultural innovation can be described as follows, including some of the reasons for its slow diffusion in practice [36,37]:

(1) In the launch phase, it had an advantage over the technological elements widely used in farming, which could have made rapid diffusion possible.

(2) Precision technology is less compatible, as farmers greatly vary in knowledge, skills and attitude toward innovations, as well as in farm size and financial background. Due to the lack of counseling support, the process of the proliferation of the new technology is slower.

(3) The application of precision crop production requires far more attention, a wider information base and, also, more accurate work.

(4) The key issue of letting farmers learn more and testing the new technology is the extension service (there have to be several specialist, scientific exhibitions and meetings in order to achieve wider diffusion).

(5) Some of the benefits of precision technology can be observed directly (material savings, improved cost-effectiveness, yield growth), similarly to extra costs and investments. However, its indirect impacts, such as the reduction of the environmental load and increased food safety, are less obvious. As long as the positive impacts of the new technology are not obvious and measurable for farmers and the perceived risk of its introduction is high, the technology will diffuse slowly, even when the financial background is sufficient.

Based on the scientific literature, the most impeding factors for the adoption of precision farming technology are high investment costs (which is sometimes true, but sometimes just supposed), the lack of managerial skills and knowledge and the farmers' attitude toward IT-supported technologies. Following the initial phase, the role of interpersonal communication channels increases (e.g., discussions with experts), and the farmer shows can also help to increase the farmers' knowledge of the new technology $[6,19,38]$. We must not forget about the important role of the extension services and communications. Also important is communicating about the economic and other benefits of the novelty to the farmers in the diffusion of precision technology [39-41]. The causes of the slow spreading process also include a lack of education and expertise [42-45].

There are many literature sources about the scientific results of the economic viability of precision farming technology. According to some researchers, precision farming technology is profitable only above 250 hectares [46]. According to others, farmers need a minimum of 1500 hectares for precision weed management or fertilization [40]. The reason for these differences is that the economical threshold level highly depends on the correlation between savings and additional costs, which is strongly determined by the heterogeneity of the given plots. If the farmers can use precision farming technology on bigger fields, they could experience more advantages of the technology. 


\section{Experimental Section}

Between the autumn of 2010 and the spring of 2011, data collection was done for examining precision farming technology among Hungarian field crop producers. This data collection contained the opinions of 72 farmers about precision farming technology. The farmers were chosen with random sampling at different agricultural exhibitions. Some interviewed farmers have used precision farming technology for years; some have planned to use this technology, and some have heard about the technology, but do not want to use it. The database has been split into three sub-samples: "non-user", "user" and "planner". The "non-user" sub-sample includes farms that use net-based soil sampling, but the treatments are not in the management zones. The "user" sub-sample includes farms that use at least one of the following elements: precision fertilization, precision plant production, precision tillage, precision weed management, precision sowing and sensors (soil, leaves, etc.). The "planner" sub-sample includes farms that now use conventional equipment, but plan to invest in precision farming technology.

The databases of the Hungarian Central Statistical Office or the Research Institute of Agricultural Economics do not include information about the usage of precision farming technology elements. Therefore, one aim of this examination is to estimate the spread of precision farming technology and to define the technology elements that are popular among Hungarian farmers. On the other hand, it is also our aim to define the knowledge about the technology and to examine the level of changes due to the adoption of precision farming technology. In the first step of the research, the following hypotheses were formulated:

Hypothesis (H1): The adoption of precision farming technology depends on economic (the size of cultivated land and the size in European size unit (ESU)) and personal factors (the age and education level of farmers).

Hypothesis (H2): The opinions of precision and non-precision farmers about the advantages and disadvantages of precision farming technology are clearly distinguishable.

The respondents of the interviews could choose their opinions about the advantages and disadvantages of precision farming technology from a list, which included 11 possible changes. They could use the Stapel scale to classify the changes resulting from the introduction of precision farming technology. The Stapel scale is a scale from -5 to +5 . If there are no changes compared to the conventional farming, 0 is used. Negative numbers mean a decrease, and positive numbers mean an increase [47]. The ANOVA test was used to examine the difference between the average values of the groups of farmers. In the case of the cross-table analyses, Cramer's V values and their significance level were examined to find the correlation between farm/farmer parameters and the usage of the technology [47].

\section{Results and Discussion}

The examined database includes the data of 72 farms. All farms produce field crops. Thanks to personal interviews, nobody was excluded from the examination because of missing data. The available sample database was divided into three sub-samples according to the farming technology used. The non-precision farmers are mostly middle aged with medium-sized cultivated land. The farmers who are younger than 40 years old with a higher education, having 30-300 hectares of cultivated land, were 
mostly classified into the sub-sample of precision farmers (Table 1). These results agree with the literature, which says that the most influential factors of its spread are the following: the size and the geographical situation of the cultivated land; the quantity and the quality of human resources and the risk-sensitivity of the manager. [39]

Table 1. Basic information about the farmers in the survey (source: own compilation based on the structured interviews).

\begin{tabular}{|c|c|c|c|c|}
\hline & & Non-user $\left(n_{1}=48\right)^{a}$ & User $\left(n_{2}=8\right)^{b}$ & Planer $\left(n_{3}=16\right)^{c}$ \\
\hline \multirow{3}{*}{ Age of farmer } & $<40$ year & $40 \%$ & $63 \%$ & $25 \%$ \\
\hline & $40-65$ year & $42 \%$ & $38 \%$ & $75 \%$ \\
\hline & $>65$ year & $19 \%$ & $0 \%$ & $0 \%$ \\
\hline \multirow{2}{*}{ Education } & Secondary & $25 \%$ & $13 \%$ & $12 \%$ \\
\hline & Higher & $32 \%$ & $63 \%$ & $57 \%$ \\
\hline \multirow{3}{*}{ Cultivated land } & $<30$ ha & $19 \%$ & $25 \%$ & $0 \%$ \\
\hline & 30-300 ha & $50 \%$ & $25 \%$ & $19 \%$ \\
\hline & $>300$ ha & $31 \%$ & $50 \%$ & $81 \%$ \\
\hline \multirow{6}{*}{$\mathrm{ESU}^{\mathrm{d}}$} & $<4 \mathrm{ESU}$ & $31 \%$ & $13 \%$ & $13 \%$ \\
\hline & 4-8 ESU & $14 \%$ & $25 \%$ & $6 \%$ \\
\hline & 8-16 ESU & $19 \%$ & $0 \%$ & $25 \%$ \\
\hline & $16-40$ ESU & $12 \%$ & $13 \%$ & $19 \%$ \\
\hline & 40-100 ESU & $7 \%$ & $25 \%$ & $25 \%$ \\
\hline & $>100$ ESU & $17 \%$ & $25 \%$ & $13 \%$ \\
\hline
\end{tabular}

${ }^{a}$ Including farms that use net-based soil sampling but the treatments are not in the management zones;

${ }^{b}$ Including farms that use at least one from the following elements: precision fertilization, precision plant production, precision tillage, precision weed management, precision sowing and sensors (soil, leaves, etc.); c Including farms that use conventional equipment, but plan to invest in precision farming technology;

${ }^{d}$ European size unit (ESU): 1 ESU = $1200 €$; based on Keszthelyi-Kovács 2002: very small ( $<4$ ESU), small (4-8 ESU), medium small (8-16 ESU), medium (16-40 ESU), large (40-100 ESU), very large (>100 ESU).

\subsection{Adoption of Precision Farming Technology in the Examined Sample}

According to the survey, precision farming technology is used by $11 \%$ of the interviewed farmers, and the rate of "non-users" was $89 \%$. Some of the "non-users" used GPS-based soil-sampling (7\%) or GPS tractor guidance $(12 \%)$, which is part of precision farming technology, but did not use any other elements, which led to site-specific and variable rate treatment. A quarter of the conventional farmers planned to adopt precision farming technology in the future. The proportion of farmers who apply precision farming technology may be higher in the database than in reality, because the structured interviews were mostly conducted at agricultural exhibitions where farmers are generally more open to novelties. Otherwise, the application of the elements of precision farming technology depends on the crops, on the field parameters, on the weed and pest population and on the management [46]. Swinton and Lowenberg-deBoer [24] state that the key factor for the spreading of precision farming technology was the increasing efficiency of input use. This means that more efficient input use makes the spread of the technology faster. 
Precision fertilization and precision plant protection were the most frequently used elements of precision farming technology according to the ranking of "users". Tractor guidance and grid soil sampling were not among the most common elements in the "user" sub-sample. Otherwise tractor guidance was a widely used element among "non-users". The reason why so many "non-users" had tractor guidance may be that the operation of this element does not need additional work and its advantages may be detected in a short time. With tractor guidance, farmers are able to treat their fields without overlapping of the treated area, and as a result of this, it is possible to decrease the inputs by about $30 \%$. Although tractor guidance is based on an IT solution, it is not a site-specific or variable rate treatment, so this is the reason why this element was not included in precision farming technology elements.

The relationship between the adoption of precision farming technology and some parameters of farms or farmers was examined with cross-table analysis. According to this, the adoption of precision farming technology only depends on the quantity of the cultivated land and the age of the farmers (Table 2). Precision farming technology has mostly been adopted by farms that have more than 300 hectares of cultivated land and by farmers younger than 40 years of age.

Table 2. The relation between the adoption of precision farming technology and some important details about farms/farmers (source: own examination based on structural interviews).

\begin{tabular}{|c|c|c|c|c|c|}
\hline \multirow{2}{*}{ Factors of adoption } & \multicolumn{2}{|c|}{ Uncertainty coefficient } & \multicolumn{2}{|c|}{ Cramer V } & \multirow{2}{*}{ Strength of relation } \\
\hline & Value & $\alpha$ & Value & $\alpha$ & \\
\hline ESU category & 0.103 & 0.25 & 0.28 & 0.35 & no \\
\hline Cultivated land & 0.135 & 0.003 & 0.314 & 0.01 & medium * \\
\hline Soil heterogenetic & 0.005 & 0.754 & 0.08 & 0.8 & no \\
\hline Ranging of technologies & 0.05 & 0.191 & 0.19 & 0.27 & no \\
\hline Age of farmer & 0.09 & 0.02 & 0.25 & 0.04 & medium * \\
\hline Education & 0.08 & 0.48 & 0.24 & 0.61 & no \\
\hline
\end{tabular}

Two thirds of the precision farmers have used more than one element of precision farming technology. These farmers have started using the technology with grid soil sampling. The farmers who used three or four different precision farming technology elements have bought all of these elements at the same time.

Based on the results of the cross-table analysis, only the size of the cultivated area and the age of the farmers had significant effects on the examined factors for the adoption of precision farming technology in practice. There were no significant correlations between the adoption of precision farming technology and the economic size unit of farms. Therefore, if the farms belonged to the bigger European size unit, this did not mean that they used precision farming technology. According to the exploratory survey, precision farming technology was adopted by farms with more than 300 hectares of cultivated and by farmers younger than 40 years of age.

\subsection{Opinion of Farmers about the Advantages and Disadvantages of Precision Farming Technology}

According to the theoretical background, the advantages of precision farming technology are the following: higher yields, better yield quality, increasing income, decreasing environmental impact and decreasing chemical use. The disadvantages of precision farming technology are the increase of working 
time and operational costs. The respondents of the interviews could choose their opinions about the advantages and disadvantages of precision farming technology from a list, which included 11 possible changes. They could use the Stapel scale to classify the changes resulting from the introduction of precision farming technology. There was no significant difference between the average values of the three sub-samples according to the ANOVA test. Otherwise, the ranking of the possible changes based on the average value (in absolute value) was completely different. There were significant differences between the opinions of the interviewed sub-samples concerning only the changes in the income and in the labor demand (Table 2).

In the rank of the changes, the most remarkable differences could be observed in the yields and the organization of work, according to the opinions of precision farmers. Otherwise, the improvement of the organization of work was in sixth or seventh place in the case of the other two sub-samples. Higher yield was in fourth place in the ranking of these two groups. All of these experiences suggest that besides the realized extra yield and cost savings, organizational change may also be noticeable by farmers in practice (Table 2).

Table 3. The opinion of the different sub-samples about the changes resulting from the adoption of precision farming technology (source: own compilation based on the structured interviews).

\begin{tabular}{|c|c|c|c|c|c|c|}
\hline \multirow{2}{*}{$\begin{array}{l}\text { The most important effects of } \\
\text { precision farming technology }\end{array}$} & \multicolumn{2}{|c|}{$\begin{array}{c}\text { User of precision } \\
\text { farming technology }\end{array}$} & \multicolumn{2}{|c|}{$\begin{array}{l}\text { Planner of precision } \\
\text { farming technology }\end{array}$} & \multicolumn{2}{|c|}{$\begin{array}{l}\text { Non-user of precision } \\
\text { farming technology }\end{array}$} \\
\hline & $\begin{array}{c}\text { Average } \\
(n=8)\end{array}$ & rank & $\begin{array}{l}\text { Average } \\
(n=16)\end{array}$ & rank & $\begin{array}{c}\text { Average } \\
(n=48)\end{array}$ & rank \\
\hline yield change & 2.75 & 1 & 2.81 & 4 & 2.26 & 4 \\
\hline income change $*$ & 2.12 & 6 & 4.44 & 1 & 2.45 & 2 \\
\hline change of chemical use & 0.63 & 9 & -2.87 & 5 & -2.36 & 3 \\
\hline change of environmental damage & -1.38 & 8 & -4.19 & 2 & -2.70 & 1 \\
\hline change of labor force needs * & 2.37 & 3 & 0.62 & 9 & 0.70 & 9 \\
\hline change of work time & 2.25 & 4 & 0.44 & 10 & 0.57 & 10 \\
\hline change of operational costs & 0.37 & 10 & 2.50 & 6 & 2.02 & 5 \\
\hline change of organization & 2.75 & 1 & 2.44 & 7 & 1.74 & 6 \\
\hline change of yield quantity & 2.25 & 4 & 2.13 & 8 & 1.66 & 7 \\
\hline change in planning process & 2.00 & 7 & 2.88 & 3 & 1.57 & 8 \\
\hline
\end{tabular}

Notes: large-scale increase, +5 ; large-scale decrease, -5 ; corresponding to conventional farming, 0 ; * the results of sub-samples are significantly different by the ANOVA test.

According to the scientific literature, the most important advantage of precision farming technology is the decrease of negative environmental impacts. In our survey, non-precision farmers placed this advantage in first place; according to precision farming planners, it was in second place, while according to precision farmers, this impact was only in eighth place. There were similar changes in terms of the chemical changes, which has a strong link with the decrease of environmental damage. The precision farmers put the chemical changes only in ninth place (Table 3).

The biggest problem with precision farming technology is that the possible advantages and disadvantages of the technology highly depend on the professional knowledge and attitude of the manager and the staff. This is the reason why, sometimes, the farmers think that the investment in 
precision farming technology will not have the expected advantages, so they do not buy other additional elements of the technology or start to use their precision equipment in a conventional way [48-50].

\subsection{Sentiment of the Variable Cost of Precision Farming Technology}

According to the "user" sub-sample, the changes resulting from the implementation of precision farming technology were smaller in practice than was expected from theoretical knowledge. This shows that the information about precision farming technology obtained from newspapers or at agricultural exhibitions concentrates on the advantages of the technology.

The opinion of the farmers about the changes in the percentage of variable costs (operational cost, herbicide cost, fertilizer cost and labor cost) resulting from the adoption of precision farming technology was examined by box-plot analysis. The box-plot analysis shows that the average opinion of the farmers about the variable cost savings is similar in the three sub-samples. According to the correlation analysis, there were no significant differences between the judgment of the cost changes and the adoption of precision farming technology. Otherwise the interval of the answers was wider in the group of precision farmers than in the other two groups. The reason for this is very simple. The cost changes of the precision farmers mostly depend on the soil parameters and weed coverage (i.e., soil heterogeneity, differences in weed species, weed coverage)

The farmers who have already used precision farming technology assessed the changes resulting from the adoption of the technology as less significant than the farmers who knew the technology only from theory. This suggests that the information about precision farming technology in newspapers or agricultural exhibitions is more optimistic than the advantages are in practice. Based on the analysis of the opinions about the variable costs by box-plot analysis, the average opinions of the non-precision farmers and the planners are very similar, but the opinions of the non-precision farmers were distributed in a wider interval. It can be stated that the biggest cost savings occurred for the cost of fertilizers and herbicides, according to the opinion of precision farmers. The precision farmers also mentioned the increase of operational costs and the costs of human resources.

\section{Conclusions}

The positive impacts of precision farming technology, which are well communicated to farmers, may be experienced in agricultural practice. One of the observations of our research, namely that "user" and "non-user" farmers believe in the positive impacts of the technology, also confirmed what is written in the literature. Even though a great part of the farmers is aware of the advantages and disadvantages of precision farming technology and there were no significant differences between the "user" and "non-user" farmers, most of them think that the investment costs of the technology are too much for them or the commitment of management to the technology is missing. Nevertheless, the commitment of management to precision farming technology is not enough if the staff do not pay enough attention to the settings of the equipment or to its maintenance.

Both the size of the cultivated land of the farms and the age of the farmers correlate significantly with the adoption of precision farming technology. These variants do not correlate with the selection of elements of precision farming technology. The income of farms does not correlate with the adoption of precision farming technology. 
According to the answers of the interviewed farmers, the most adopted element of precision farming technology is tractor guidance (it was used at six farms, precision and conventional farms, as well). The use frequencies of the net-based soil sampling and of the off-line precision nutrient supply (which is strongly related to soil sampling) and of the off-line precision plant protection were similar. The reason for the lack of on-line precision farming technology elements is that the investment cost of these technology elements is much higher than the off-line equipment, while the possible savings are the same.

The rankings of the effects of precision farming technology are different in the group of users, the group of planners and the group of non-users of precision farming technology. For the precision farmers, the most important advantages of this technology are better organization and yield increase (in quantity and in quality) and the increase in profit. The most important disadvantages are the increase of human resource demand and working time.

Summarizing our research results, it can be stated that less Hungarian farmers use several element of precision technology than was expected. In spite of the fact that technological resources for producers are available, crop protection is the least used among the existing precision crop production components; yield mapping, precision fertilizing and lime management are more frequently used. Our research confirmed the results of Timmermann et al. [51] and Jensen et al. [52]. To strengthen the diffusion of more elements in farming practice, it is necessary to communicate not only the advantages of increasing the efficiency of input use [24], but other indirect advantages (reduction of environmental burden, increasing precise thinking, better management).

Precision crop production is an environmentally-friendly farming practice. The greening impact, i.e., the decreasing use of agrochemicals, can be greater than the savings reached by leaving the land fallow, because this practice is preferential in marginal areas, where agrochemical use was originally lower. Farmers who leave their land fallow perform more intensive production on their other land in order to compensate for the yield losses. Precision farming could be one of the means of enhancing the green component of Pillar 1 of the Common Agricultural Policy (CAP) (2014-2020), but it has not been implemented among the components. We agree with those who called attention to alternative solutions during the discussion process of the CAP proposals and think it will have higher significance in the future.

\section{Acknowledgment}

The paper was partly supported by the Hungarian Scientific Research Found (Országos Tudományos Kutatási Alap; K109026 OTKA).

\section{Author Contributions}

Enikő Lencsés carried out the primary survey among the Hungarian farmers and made the analyses. István Takács took part in the analyses and in literature background development. Katalin Takács-György was the supervisor in the survey and performed the literature groundwork. All authors have read and approved the final manuscript.

\section{Conflicts of Interest}

The authors declare no conflict of interest. 


\section{References}

1. Podmaniczky, L.; Ángyán, J.; Illés, B.C.; Straub, T. Farming in Protected Landscape: Economic Analysis of the Possibilities for Sustainable Agriculture; IUCN: Gland, Switzerland, 1997; p. 62.

2. Illés, B.C.; Dunay, A.; Vida, A. Microeconomic modelling methods for utilizing renewable agricultural energy resources. In The Evaluation of Natural Resources; Ugrósdy, G., Molnár, J., Szücs, I., Eds.; Agroinform Kiadó: Budapest, Hungary, 2014; pp. 273-292.

3. Chilinsky, G.; Heal, G.; Vercelli, A. Sustainability: Dynamics and Uncertainty; Kluwe Academic Publication: Dordrecht, The Netherlands, 1998; p. 249.

4. Swinton, S.M. Economics of site specific weed management. Weed Sci. 2005, 53, 259-263.

5. Szabó, G.; Katonáné-Kovács, J. A fenntarthatóság, környezetvédelem, hatékonyság (Sustainability, environment protection, efficiency). In Hatékonyság a Mezögazdaságban: Elmélet és Gyakorlat (Efficiency in Agriculture: Theory and Practice); Szücs, I., Farkasné-Fekete, M., Eds.; Agroinform Kiadó: Budapest, Hungary, 2008; pp. 319-337.

6. Maciejczak, M. The concept of SMART specialization in the development of agribusiness sector on the example of clusters of innovations in agribusiness in Mazovia Province. Ann. Pol. Assoc. Agric. Agribus. Econ. 2012, 14, 169-176.

7. Daróczi, M. The Contribution of Agricultural Machinery to Sustainable Agriculture. In Proceedings of the First International Symposium on Agricultural Engineering, Belgrade, Serbia, 4-6 October 2013; pp. 19-27.

8. Milics, G.; Smuk, N.; Virág, I.; Neményi, M. Precision Agriculture-Technical Development for a Sustainable Agriculture. In Proceedings of the International Scientific Conference on Sustainable Development \& Ecological Footprint, Sopron, Hungary, 26-27 March 2012; p. 5.

9. Barkaszi, L.; Arutyunjan, A.; Takacsne-Gyorgy, K. Optimisation of the weed sampling system from an economic point of view on wheat (Triticum aestivum) stable with sunflower (Helianthus annuus) forecrop. Cereal Res. Commun. 2007, 35, 1527-1537.

10. Milics, G. Mapping soil properties for precision farming. In Proceedings of the 12th Alps-Adria Scientific Workshop, Opatija, Croatia \& Doberdò, Venezia, Italy, 18-22 March 2013; pp. 405-408.

11. Takács-György, K.; Takács, I. Economic analysis of precision weed management. Cereal Res. Commun. 2009, 37, 597-605.

12. Barosso, J.; Fernandez-Quintanilla, C.; Maxwell, B.D.; Rew, I.J. Simulating the effects of weed spatial pattern and resolution of mapping and spraying on economics of site-specific management. Weed Res. 2004, 44, 460-468.

13. Maxwell, B.D.; Luschei, E.C. Justification for site-specific weed management based on ecology and economics. Weed Sci. 2005, 53, 221-227.

14. Panten, K.; Haneklaus, S.; Rogasik, J.; Schnug, E. Predicting sugar beet yield variability using yield maps of combinable crops and the "monitor pedo cell" approach. Landbauforschung Völkenrode 2005, 286, 65-70.

15. Auernhammer, H. Precision farming-The environmental challenge. Comput. Electron. Agric. 2001, 30, 31-43. 
16. Neményi, M.; Pecze, Z.; Mesterházi, P.Á.; Németh, T. A precíziós-helyspecifikus növénytermesztés müszaki és térinformatikai feltételrendszere (Technical and GIS requirements of site-specific crop production). Növénytermelés 2001, 50, 419-430.

17. Blackshaw, R.E.; O’Donovan, J.T.; Harker, K.N.; Clayton, G.W.; Stougaard, R.N. Reduced herbicide doses in field crops: A review. Weed Biol. Manag. 2006, 6, 10-17.

18. Batte, M.; van Buren, F. Precision farming - Factors influencing profitability. In Proceedings of the Northern Ohio Crops Day Meeting, Wood County, OH, USA, 21 January 1999.

19. Pecze, Z. Precíziós gazdálkodás—csökkenő költségek (Precision agriculture—Decreasing costs). IKR Magazin 2006, Summer, 9.

20. Rider, T.W.; Vogel, J.W.; Dille, J.A.; Dhuyvetter, K.C.; Kastens, T.L. An economic evaluation of site-specific herbicide application. Precis. Agric. 2006, 7, 379-392.

21. Arnholt, M.; Batte, M.T.; Prochaska, S. Adoption and Use of Precision Farming Technologies: A Survey of Central Ohio Precision Farmers; The Ohio State University: Columbus, OH, USA, 2001.

22. Lowenberg-DeBoer, J.; Swinton, S.M. Economics of site-specific management in agronomic crops. In The State of Site-specific Management for Agricultural Systems; Pierce, F.J., Sadler, E.J., Eds.; American Society of Agronomy, Crop Science Society of America and Soil Science Society of America: Madison, WI, USA, 1997; pp. 369-396.

23. Takács-György, K; Takács, I. Risk assessment and examination of economic aspects of precision weed management. Sustainability 2011, 3, 1114-1135.

24. Swinton, S.M.; Lowenberg-DeBoer, J. Global adoption of precision agriculture technologies: Who, when and why? In Proceedings of the 3rd European Conference on Precision Agriculture, Montpellier, France, 18-21 June 2001; pp. 557-562.

25. Wilson, C.; Tisdell, C.A. Why farmers continue to use pesticides despite environmental, health and sustainability costs. Ecol. Econ. 2001, 39, 449-462.

26. Pedersen, S.M.; Fountas, S.; Blackmore, B.S.; Gylling, M.; Pedersen, J.L. Adoption and perspectives of precision farming in Denmark. Acta Agric. Scand. Sect. B 2010, 54, 2-8.

27. Takács, I.; Baranyai, Z. Role of trust in cooperation of farmers from the aspect of new institutional economics. Ann. Pol. Assoc. Agric. Agribus. Econ. 2010, 6, 179-184.

28. Takács, I. Gépkör-Jó alternatíva (Machinery rings—Good alternative)? Gazdálkodás 2000, 44, 44-55.

29. Baranyai, Z.; Szabó, G.G.; Vásáry, M. Analysis of machine use in Hungarian agriculture-Is there any future for machinery sharing arrangements? Ann. Pol. Assoc. Agric. Agribus. Econ. 2014, 16, 24-30.

30. Baranyai, Z.; Takács, I. Characteristics of machine utilization of plant production farms in Hungary. Hung. Agric. Eng. 2008, 21, 35-37.

31. Szabó, G.G. "Cooperative identity": A theoretical concept for economic analysis of the dynamics. Stud. Agric. Econ. 2006, 105, 5-22.

32. Bakucs, L.Z.; Fertő, I.; Szabó, G.G. The Impact of Trust on Cooperative Membership Performance and Satisfaction in the Hungarian Horticulture. In Proceedings of the 104th Seminar, European Association of Agricultural Economists, Budapest, Hungary, 5-8 September 2007; pp. 382-392.

33. Szabó, G.G. Szövetkezetek az Élelmiszergazdaságban (Cooperatives in Agribusiness); Agroinform Kiadó: Budapest, Hungary, 2011; p. 256. 
34. Fenyvesi, L.; Erdeiné Késmárky-Gally, Sz. Boosting the competitiveness of agricultural production in Hungary through an innovation system. Stud. Agric. Econ. 2012, 114, 106-110.

35. Rogers, E.M. Diffusion of Innovation; Free Press: New York, NY, USA, 1962.

36. Takács-György, K. Economic aspects of an agricultural innovation-Precision crop production. Appl. Stud. Agribus. Commer. 2012, 6, 51-57.

37. Takács-György, K.; Lencsés, E.; Takács, I. Economic benefits of precision weed control and why its uptake is so slow. Stud. Agric. Econ. 2013, 115, 40-46.

38. Csizmadia, Z. Együttmüködés és Újitóképesség: Kapcsolati Hálózatok és Innovációs Rendszerek Regionális Sajátosságai (Cooperation and Ability for Renewing. Regional Characteristics of Networks); Napvilág Kiadó: Budapest, Hungary, 2009; p. 254.

39. Griffin, T.W.; Lowenberg-DeBoer, J.; Lambert, D.M.; Peone, J.; Payne, T.; Daberkow, S.G. Adoption, Profitability, and Making Better Use of Precision Farming Data; Purdue University: West Lafayette, IN, USA, 2004; p. 20.

40. Kalmár, S. Új Mezőgazdasági Technológiák Üzemgazdasági Értékelése, az Optimális Üzemméret Kialakítása Tükrében (Evaluation of New Agricultural Technologies in the Mirror of Optimal Farm Sizes). Ph.D. Thesis, West-Hungarian University, Mosonmagyaróvár, Hungary, June 2010; p. 121.

41. Kutter, T.; Tiemann, S.; Siebert, R.; Fountas, M. The role of communication and co-operation in the adoption of precision farming. Precis. Agric. 2011, 12, 2-17.

42. Attanandana, T.; Yost, R.; Verapattananirund, P. Empowering farmer leaders to acquire and practice site-specific nutrient management technology. J. Sustain. Agric. 2007, 30, 87-104.

43. Takács, I. Szempontok a Müszaki-fejlesztési Támogatások Közgazdasági Hatékonyságának Méréséhez (Aspects of measuring the economic efficiency of subsidies for improving technical development). In Müszaki Fejlesztési Támogatások Közgazdasági Hatékonyságának Mérése; Takács, I., Ed.; Szent István Egyetemi Kiadó: Gödöllő, Hungary, 2008; pp. 9-48.

44. Magda, S.; Dinya, L.; Magda, R. Innováció és Kutatás-Fejlesztés (Innovation and R\&D). Magyar Tudomány 2008, 169, 192-203.

45. Nábrádi, A. Role of innovations and knowledge-Infrastructure and institutions. In Proceedings of the 113th Seminar, European Association of Agricultural Economists, Belgrade, Serbia, 9-11 December 2009.

46. Székely, C.; Kovács, A.; Györök, B. The practice of precision farming from an economic point of view. Gazdálkodás 2000, 13, 56-65.

47. Sajtos, L.; Mitev, A. SPSS Kutatási és Adatelemzési Kézikönyv; Alinea Kiadó: Budapest, Hungary, 2007.

48. Takács-György, K.; Györök, B.; Kovács, A. The effects of precision farming on the use of chemicals. In Proceedings of the Xth Congress of the EAAE, Zaragoza, Spain, 28-31 August 2002; pp. 1-8.

49. Lencsés, E. Different investment possibilities of precision farming technology in Hungary. In Modern Management in the 21st Century-Theoretical and Practical Issues; Ubreziová, I., Horska, E., Eds.; Slovak University of Agriculture: Nitra, Slovakia, 2013; pp. 208-220.

50. Daberkow, S.; McBride, W. Farm and operator characteristics affecting the awareness and adoption of precision farming agriculture technologies in the US. Precis. Agric. 2003, 4, 163-177. 
51. Timmermann, C.; Gerhards, R.; Krohmann, P.; Kühbauch, W. The economic impact of site specific weed control. Precis. Agric. 2003, 4, 249-260.

52. Jensen, H.G.; Jacobsen, L.; Pedersen, S.M.; Tavella, L. Socioeconomic impact of widespread adoption of precision farming and controlled traffic systems in Denmark. Precis. Agric. 2012, 13, 661-677.

(C) 2014 by the authors; licensee MDPI, Basel, Switzerland. This article is an open access article distributed under the terms and conditions of the Creative Commons Attribution license (http://creativecommons.org/licenses/by/4.0/). 